\title{
ARTICLE \\ Assessment of Rainwater and Groundwater Quality in Izombe Town, Oguta Local Government Area of Imo State
}

\author{
S. I. Akopunwanne ${ }^{1}$ E. T. Oparaocha ${ }^{1}$ C. D. Onwuka ${ }^{2^{*}}$ \\ 1. Department of Public Health, Federal University of Technology, Owerri, Imo State, Nigeria \\ 2. Department of Environmental and Applied Biology, Imo State University Owerri, Nigeria
}

\section{ARTICLE INFO}

Article history

Received: 16 August 2021

Accepted: 16 September 2021

Published Online: 28 September 2021

\section{Keywords:}

Assessment

Rainwater

Groundwater

Coliform

Izombe

\begin{abstract}
Rainwater and groundwater quality in Izombe were assessed. Five water samples were collected from five (5) different locations, with at least one location from one of the four autonomous communities in Izombe, Oguta L.G.A of Imo State. The physicochemical and microbial parameters of rainwater and groundwater samples from Umuakpa, Ndeuloukwu, Ugbele, Ndioko, and Orsu were assessed using Varian Atomic Absorption Spectrophotometer (AAS). The study was aimed to assess the physicochemical and microbial qualities of groundwater and rainwater in Izombe and how these affect their health as individual members of the community, and their environment when compared to WHO standards. The water samples were collected from five different locations, with at least one location from each of the four autonomous communities, and were assessed. The result indicated that rainwater and groundwater pollutants in the community were turbidities, ammonia, copper and temperatures $7.59 \pm 0.02 \mathrm{ph}, 6.42 \pm 0.28$ nitrate, $59.56 \pm 0.50$ ammonia, $0.29 \pm 0.07$ phosphate, $0.88 \pm 0.03$ iron, copper, lead, nickel, aluminum, mercury, manganese, cadmium, bacteria count, coliform count, and E-coli. Also, all the pollutant parameters were identified, only iron, copper, aluminum, and bacteria count were not identified as being associated with petroleum products and exploratory activities. This research has broadened the understanding of the suitability of Izombe water sources for both consumption and other purposes. The findings show that the rain and groundwater sources of the community are not fit for human consumption, due to the contaminants inherent in them, attributed majorly to the oil production activities in the area which corroborates other research studies.
\end{abstract}

of the most important to biological systems. Glen further states that water is the only common pure substance that exists naturally in all three states of matter (solid, liquid, gas). It also covers 75 percent of the earth and composes roughly 78 percent of the human body. Water is the most abundant molecule on Earth's surface, composing 70-75\% of the Earth's surface as a liquid and solid-state in addition

*Corresponding Author:

C. D. Onwuka,

Department of Environmental and Applied Biology, Imo State University Owerri, Nigeria;

Email:dvmoore37@gmail.com 
to being found in the atmosphere as a vapor.

Izombe community is one of the oil-producing areas in the Niger Delta region of Nigeria. However, before the discovery of crude oil in the area, the people of Izombe traditionally as a sub-Sahara African community was of an agrarian economy, which covers farming, palm wine tapping, and fishing, with a very small industrial sector. Even with the discovery of crude oil, the people of Izombe still depend on their land and water for their agrarian economy. The income of most common people in the area comes from staple food and palm produce. Agriculture provides about $60 \%$ of the employment and more than $70 \%$ of the total economic exchange earnings. About $90 \%$ of their food supplies and consumption is locally produced.

Just like any other agrarian community, it is obvious that the people of Izombe depend greatly on the quality of rainwater and groundwater for their economic development. The availability and quality of water (rain or ground) do not only control the level of agrarian productivity but also determine the level of good health enjoyed by the people of any environment. Researches and surveys have however shown that geographical location, human activities as well as industrial emissions, contribute very largely to the variability in quality and availability of rain and groundwater. These factors are therefore of great importance to the physical, economic and environmental development of Izombe.

A state that recognized that environmental factors can affect health in its broadest sense ${ }^{[4]}$, it is often difficult to isolate and quantify the risk that might arise from these exposures because of their close interactions with other health determinants'. One of the other health determinants that ${ }^{[4]}$ made efforts to identify is 'Water'. It is a major health determinant, which interacts with other exposures to influence that state of human and environmental health. Its positive or negative influence on health, therefore, depends on the quality of the water. This position is in agreement with the ${ }^{[5]}$ which attributes an estimate of $24 \%$ of the global disease burden to environmental factors, whilst in the United Kingdom, the estimate is about $14 \%$. Unfortunately, the understanding of the complex and multi-faceted relationships that exist between exposures to environmental and health risks is limited.

Some scholars like ${ }^{[6,7]}$, have come to a common opinion that water as rain, acquires its salinity and bacteriological composition partly as it passes through the atmosphere by dissolving air-borne particulates from natural or industrial activities and water-soluble gases, as well as absorbing air-borne microbes. Its quality may further degrade as it infiltrates into the soil, causing leaching and weathering of the geological medium, which results in the dissolution or precipitation of some mineral constituents and human chemical deposits in the soil, which add to groundwater contamination.

It was observed that previous studies on the quality of water resources in the tropical African environment have largely been restricted to surface and groundwater to the negligence of rainwater ${ }^{[8]}$. Also it was opined that this negligence is predicated upon the assumption that rainwater is usually very pure and therefore needs very little investigation ${ }^{[8]}$.

The vulnerability therefore of rainwater and groundwater to quality degradation from human activities makes a periodic assessment of their qualities necessary. In consideration of the above facts, the researcher desires to assess the quality of rain and groundwater in Izombe. This is necessary not just because water quality controls the level of healthy living of the people, but also with the consciousness that the area is an agrarian environment, where the level of agricultural productivity depends on rain and groundwater qualities. The impetus for this study on rain and groundwater quality assessment is also driven by the additional fact that Izombe is an oil-producing community, with the assumptions that chemical emissions and spillages from the oil production activities have possibilities of impairing water qualities in the area.

In this study, therefore, the researcher seeks to asses, analyze and determine the quality of rain and groundwater in Izombe community of Oguta Local Government Area of Imo State. To achieve this purpose, this study considers the various factors contributing to the quality of rain and groundwater, with a special focus on oil-producing communities. The study also focuses on environmental and health implications of the water quality and the various negative impacts of agricultural and oil production activities on water quality in Izombe as an agrarian and oil-producing community.

\section{Materials and Methods}

\subsection{Description of Study Area}

Izombe autonomous community is one of the 
communities in the Oguta Local Government Area of Imo State. The community is located on the western geographical axis of Imo State. Imo State is one of the 36 states of the Federal Republic of Nigeria, with Owerri as the capital and the largest city. The state was created on February 3, 1976, from the old East Central State. The state lies between latitude $4.45^{\circ} \mathrm{N}$ and $7.15^{\circ} \mathrm{N}$ and longitude $6.50^{\circ} \mathrm{E}$ and $7.25^{\circ} \mathrm{E}$. It occupies the Lower Niger Basin and Upper Imo River. The state shares borders in the East with Abia State, in the West with River Niger and Delta state, in the North with Anambra State, while Rivers State is in the South. Imo state has a population of about 4.8million persons. Imo State which covers approximately a land area of 12,689 square kilometers, has (27) twentyseven local government areas, of which Oguta local government is one. The density population of the Oguta local government area where Izombe community belongs is about 230 persons per square kilometer.

Izombe is one of the oil-producing communities in the Niger Delta region of Nigeria. Before the discovery of crude oil in the area, the people of Izombe traditionally a sub-Sahara African community is of an agrarian economy, which covers farming, Palm oil production, palm wine tapping, and fishing, with a very small industrial sector. It is not farfetched therefore why the researcher considered Izombe as the best area for this study. The activities of oil companies and other allied industries make the area prone to daily pollution from hydrocarbons and other industrial chemical and solid pollutants. Above all, the community depends daily on the water for their daily living and economic activities. The quality of water, therefore, is a primary factor in Izombe as an oil-producing community.

\subsection{Sample Collection}

Five (5) water samples were obtained from five (5) different places, with at least one sample collected from one of the four autonomous communities in Izombe (see Tables 1 and 2). Twenty villages were divided into four autonomous groups based on their geographical distribution, and 20 samples were taken from each group. The locations from which the samples were taken are given in Table 1. Distance from the borehole to a potential source of contamination was measured with a standard meter rule and recorded. The determination of dissolved oxygen and temperature were measured using $\mathrm{DO}_{2}$ meter.
The groundwater samples from the 5 distinct boreholes were labeled GW1-GW5, while the rainfall samples were called RW1-RW5 samples for convenience. In August of 2017, groundwater samples were obtained in the early morning hours when newly pumped from the ground, following the Nigerian Standard for Drinking Water Quality (NSDQW) standard practices for Water Quality Analysis, and rainwater was collected directly from the cloud into a sterile wide-mouthed basin that was put on top of an empty large drum, avoiding splashes of sand and other debris from the land. All bottles (Teflon beaker) were used for sample collection and disinfected, cleaned, and rinsed with distilled water before collection as part of quality control protocols. Before the final water sampling, the bottles were rinsed three times with the sample water at the place of collection. To avoid contamination of the water by the hands or fingers, the bottles were held at the bottom while being filled ${ }^{[9]}$. All of the sample containers were maintained in iceboxes until they were transported to the lab for analysis. Also, the determination of heavy metals using atomic absorption spectrophotometer (AAS) was carried out using FS 240 varian atomic absorption spectrophotometer, acetylene gas, and air oxidant gas etc with 1000 ppm AI standard solution.

\subsection{Tests for Physicochemical and Microbiological Parameters}

The following microbiological parameters were tested on the samples taken from the various units: Biochemical Oxygen Demand (BOD), Total Viable Count (TVC), and coliform test. The analysis was carried out using a membrane filter (MF) and a pour plate technique. According to the processes specified, the chemical parameters were: hardness, sulfate $\left(\mathrm{SO}_{4}{ }^{2-}\right)$, nitrate $\left(\mathrm{NO}^{3-}\right)$, calcium $\left(\mathrm{Ca}^{2+}\right)$, zinc $(\mathrm{Zn})$, manganese $(\mathrm{Mn})$, lead $(\mathrm{Pb})$, iron $(\mathrm{Fe})$, magnesium $(\mathrm{Mg})$, alkalinity $\left(\mathrm{CaCO}_{3}\right)$, ammonia $\left(\mathrm{NH}_{3}\right)$, and $\mathrm{pH}$. Taste, odor, and temperature were determined by physically inspecting the samples. The concentration of suspended and dissolved solids, which yielded the total dissolved solids of the individual samples, was also evaluated ${ }^{[10]}$. 


\section{Results}

Table 1. Groundwater physicochemical and microbial parameters from the five (5) communities in Izombe

\begin{tabular}{|c|c|c|c|c|c|c|c|}
\hline PARAMETERS & UMUAKPA & NDEULOUKWU & UGBELE & NDIOKO & ORSU & Mean \pm SD & WHO STD \\
\hline Temperature ${ }^{\circ} \mathrm{C}$ & $28.03 \pm 0.06^{\mathrm{a}}$ & $28.13 \pm 0.15^{\mathrm{a}}$ & $27.93 \pm 0.16^{\mathrm{a}}$ & $27.77 \pm 0.15$ & $28.60 \pm 0.01$ & $28.09 \pm 0.15$ & $20-30$ \\
\hline Conductivity $(\mu \mathrm{s} / \mathrm{cm})$ & $13.33 \pm 0.57^{\mathrm{b}}$ & $30.18 \pm 0.15^{\mathrm{b}}$ & $37.90 \pm 0.14^{\mathrm{b}}$ & $32.67 \pm 0.58^{\mathrm{a}}$ & $15.00 \pm 1.00^{\mathrm{a}}$ & $25.82 \pm 0.14$ & 100 \\
\hline Colour (PCU) & $4.33 \pm 1.15^{\mathrm{c}}$ & $59.27 \pm 0.23^{\mathrm{c}}$ & $25.85 \pm 0.13^{\mathrm{c}}$ & $13.68 \pm 0.58^{\mathrm{b}}$ & $16.33 \pm 0.58^{\mathrm{b}}$ & $23.89 \pm 0.25$ & 15.00 \\
\hline Turbidity (NTU) & $1.72 \pm 0.02^{\mathrm{d}}$ & $24.82 \pm 0.08^{\mathrm{d}}$ & $0.00 \pm 0.00^{\mathrm{d}}$ & $5.63 \pm 0.01$ & $5.80 \pm 0.02$ & $7.59 \pm 0.02$ & 5.00 \\
\hline $\mathrm{Ph}$ & $5.57 \pm 0.12^{\mathrm{e}}$ & $6.90 \pm 0.15^{\mathrm{e}}$ & $5.53 \pm 0.26^{\mathrm{e}}$ & $6.73 \pm 0.06$ & $7.37 \pm 0.15$ & $6.42 \pm 0.28$ & $6.5-8.5$ \\
\hline $\begin{array}{c}\text { Dissolved Oxygen } \\
(\mathrm{mg} / \mathrm{l})\end{array}$ & $7.83 \pm 0.11$ & $6.89 \pm 0.10^{\mathrm{f}}$ & $7.95 \pm 0.08$ & $5.13 \pm 0.15$ & $6.87 \pm 0.06$ & $6.93 \pm 0.09$ & $>4$ \\
\hline $\begin{array}{l}\text { Total dissolved solids } \\
(\mathrm{mg} / \mathrm{l})\end{array}$ & $9.10 \pm 0.10 \mathrm{f}$ & $19.54 \pm 0.06^{\mathrm{g}}$ & $24.66 \pm 0.03^{\mathrm{f}}$ & $20.77 \pm 0.06^{\mathrm{c}}$ & $9.73 \pm 0.02^{\mathrm{c}}$ & $16.76 \pm 0.04$ & 250 \\
\hline $\begin{array}{c}\text { Total suspended solids } \\
(\mathrm{mg} / \mathrm{l})\end{array}$ & $1.07 \pm 0.12 \mathrm{~g}$ & $14.19 \pm 0.17^{\mathrm{h}}$ & $4.21 \pm 0.21^{\mathrm{g}}$ & $2.93 \pm 0.12^{\mathrm{d}}$ & $3.33 \pm 0.58^{\mathrm{d}}$ & $5.14 \pm 0.15$ & 50 \\
\hline Chlorine (mg/l) & $0.02 \pm 0.01$ & $0.25 \pm 0.03$ & $0.11 \pm 0.01$ & $0.25 \pm 0.01$ & $0.17 \pm 0.02$ & $0.16 \pm 0.02$ & $0.2-0.25$ \\
\hline Nitrate (mg/l) & $121.33 \pm 0.25^{\mathrm{h}}$ & $31.26 \pm 0.22^{\mathrm{i}}$ & $87.33 \pm 0.07^{\mathrm{h}}$ & $25.20 \pm 0.10$ & $32.67 \pm 0.58$ & $59.56 \pm 0.50$ & 40.00 \\
\hline Nitrate-Nitrogen (mg/l) & $27.47 \pm 0.15^{\mathrm{i}}$ & $9.43 \pm 0.04^{j}$ & $19.63 \pm 0.07^{\mathrm{i}}$ & $5.70 \pm 0.10$ & $7.20 \pm 0.20$ & $13.89 \pm 0.3$ & 15.00 \\
\hline Ammonia (mg/l) & $0.26 \pm 0.02$ & $0.42 \pm 0.11$ & $0.38 \pm 0.03$ & $0.30 \pm 0.01$ & $0.12 \pm 0.02$ & $0.29 \pm 0.07$ & 0.30 \\
\hline Phosphate (mg/l) & $1.13 \pm 0.15$ & $1.22 \pm 0.03^{\mathrm{k}}$ & $0.52 \pm 0.03$ & $0.43 \pm 0.06^{\mathrm{e}}$ & $1.10 \pm 0.17$ & $0.88 \pm 0.03$ & 5.0 \\
\hline Phosphorus (mg/l) & $0.33 \pm 0.15$ & $0.44 \pm 0.05$ & $0.12 \pm 0.03$ & $0.20 \pm 0.02$ & $0.32 \pm 0.03$ & $0.28 \pm 0.02$ & 0.3 \\
\hline Sulphate (mg/l) & $5.17 \pm 0.15^{\mathrm{j}}$ & $5.21 \pm 0.21^{\mathrm{L}}$ & $5.00 \pm 0.02^{\mathrm{j}}$ & $5.13 \pm 0.15^{\mathrm{f}}$ & $5.13 \pm 0.15^{\mathrm{e}}$ & $5.13 \pm 0.15$ & 100 \\
\hline Zinc (mg/l) & $0.00 \pm 0.00$ & $0.02 \pm 0.00$ & $0.03 \pm 0.00$ & $0.03 \pm 0.00$ & $0.00 \pm 0.00$ & $0.02 \pm 0.01$ & 5.0 \\
\hline $\begin{array}{c}\text { Alkalinity }(\mathrm{mg} / \mathrm{l}) \\
\mathrm{CaCO}_{3}\end{array}$ & $19.67 \pm 0.58^{\mathrm{k}}$ & $5.21 \pm 0.21^{\mathrm{m}}$ & $60.00 \pm 0.03^{\mathrm{k}}$ & $4.67 \pm 0.58^{\mathrm{g}}$ & $50.03 \pm 0.06^{\mathrm{f}}$ & $27.92 \pm 0.03$ & 200 \\
\hline Chromium (mg/l) & $0.00 \pm 0.00$ & $0.02 \pm 0.00$ & $0.00 \pm 0.00$ & $0.01 \pm 0.00$ & $0.01 \pm 0.01$ & $0.01 \pm 0.00$ & 0.05 \\
\hline Calcium (mg/l) & $0.22 \pm 0.02$ & $0.12 \pm 0.02$ & $0.19 \pm 0.02^{\mathrm{L}}$ & $0.12 \pm 0.02$ & $0.18 \pm 0.02$ & $0.17 \pm 0.02$ & 150 \\
\hline Magnesium (mg/l) & $0.00 \pm 0.00$ & $0.00 \pm 0.00$ & $0.00 \pm 0.00$ & $0.00 \pm 0.00$ & $0.01 \pm 0.01$ & $0.002 \pm 0.01$ & 150 \\
\hline $\operatorname{Iron}(\mathrm{mg} / \mathrm{l})$ & $0.90 \pm 0.01$ & $0.53 \pm 0.02$ & $0.03 \pm 0.01^{\mathrm{m}}$ & $0.13 \pm 0.01$ & $0.06 \pm 0.01$ & $0.33 \pm 0.01$ & 0.3 \\
\hline Copper (mg/l) & $0.92 \pm 0.02$ & $2.72 \pm 0.09^{\mathrm{n}}$ & $0.13 \pm 0.01$ & $7.45 \pm 0.02^{\mathrm{h}}$ & $0.64 \pm 0.02$ & $2.37 \pm 0.03$ & 1.0 \\
\hline Lead (mg/l) & $0.87 \pm 0.02$ & $0.29 \pm 0.02$ & $0.78 \pm 0.03$ & $0.21 \pm 0.01$ & $0.36 \pm 0.02$ & $0.50 \pm 0.01$ & 0.05 \\
\hline Nickel (mg/l) & $0.00 \pm 0.00$ & $0.00 \pm 0.00$ & $0.00 \pm 0.00$ & $0.00 \pm 0.00$ & $0.00 \pm 0.00$ & $0.00 \pm 0.00$ & 0.02 \\
\hline Aluminium (mg/l) & $1.61 \pm 0.01$ & $1.93 \pm 0.05$ & $1.33 \pm 0.03$ & $1.75 \pm 0.01$ & $1.62 \pm 0.02$ & $1.65 \pm 0.02$ & 0.20 \\
\hline Mercury (mg/l) & $2.30 \pm 0.10^{\mathrm{L}}$ & $2.54 \pm 0.15$ & $5.02 \pm 0.06$ & $0.70 \pm 0.01^{\mathrm{i}}$ & $1.21 \pm 0.02^{\mathrm{g}}$ & $2.35 \pm 0.04$ & 0.002 \\
\hline Manganese (mg/l) & $0.22 \pm 0.01$ & $0.08 \pm 0.00$ & $0.31 \pm 0.02$ & $0.33 \pm 0.00$ & $0.14 \pm 0.00$ & $0.22 \pm 0.01$ & 0.2 \\
\hline Cadmium (mg/l) & $0.00 \pm 0.00$ & $0.00 \pm 0.00$ & $0.00 \pm 0.00$ & $0.00 \pm 0.00$ & $0.00 \pm 0.00$ & $0.00 \pm 0.00$ & 0.005 \\
\hline BOD (mg/l) & $9.17 \pm 0.15^{\mathrm{m}}$ & $2.53 \pm 0.38^{\circ}$ & $10.51 \pm 0.31^{\mathrm{n}}$ & $1.11 \pm 0.01$ & $1.30 \pm 0.01$ & $4.92 \pm 0.01$ & 30 \\
\hline $\begin{array}{l}\text { Bacterial count } \\
(\mathrm{CFU} / 100 \mathrm{ml})\end{array}$ & $53.00 \pm 1.00^{\mathrm{n}}$ & $12.00 \pm 1.00^{\mathrm{p}}$ & $57.33 \pm 0.58^{\circ}$ & $6.67 \pm 0.58^{\mathrm{j}}$ & $8.67 \pm 0.58$ & $27.53 \pm 0.58$ & $5-10$ \\
\hline $\begin{array}{l}\text { Coliform count } \\
(\mathrm{cfu} / 100 \mathrm{ml})\end{array}$ & $31.33 \pm 1.52^{\circ}$ & $2.33 \pm 0.58^{\mathrm{q}}$ & $34.00 \pm 0.00^{\mathrm{p}}$ & $3.00 \pm 1.00^{\mathrm{k}}$ & $4.33 \pm 0.58$ & $14.99 \pm 0.24$ & 10 \\
\hline E.coli (cfu/100ml) & $10.67 \pm 0.58^{\mathrm{p}}$ & $2.33 \pm 0.58^{\mathrm{r}}$ & $11.00 \pm 0.00^{\mathrm{q}}$ & $6.67 \pm 0.58$ & $4.00 \pm 1.00$ & $6.93 \pm 0.29$ & 0 \\
\hline
\end{tabular}


Journal of Environmental \& Earth Sciences | Volume 03 | Issue 02 | October 2021

Table 2. Rainwater physicochemical and microbiological parameters from the five (5) communities in Izombe

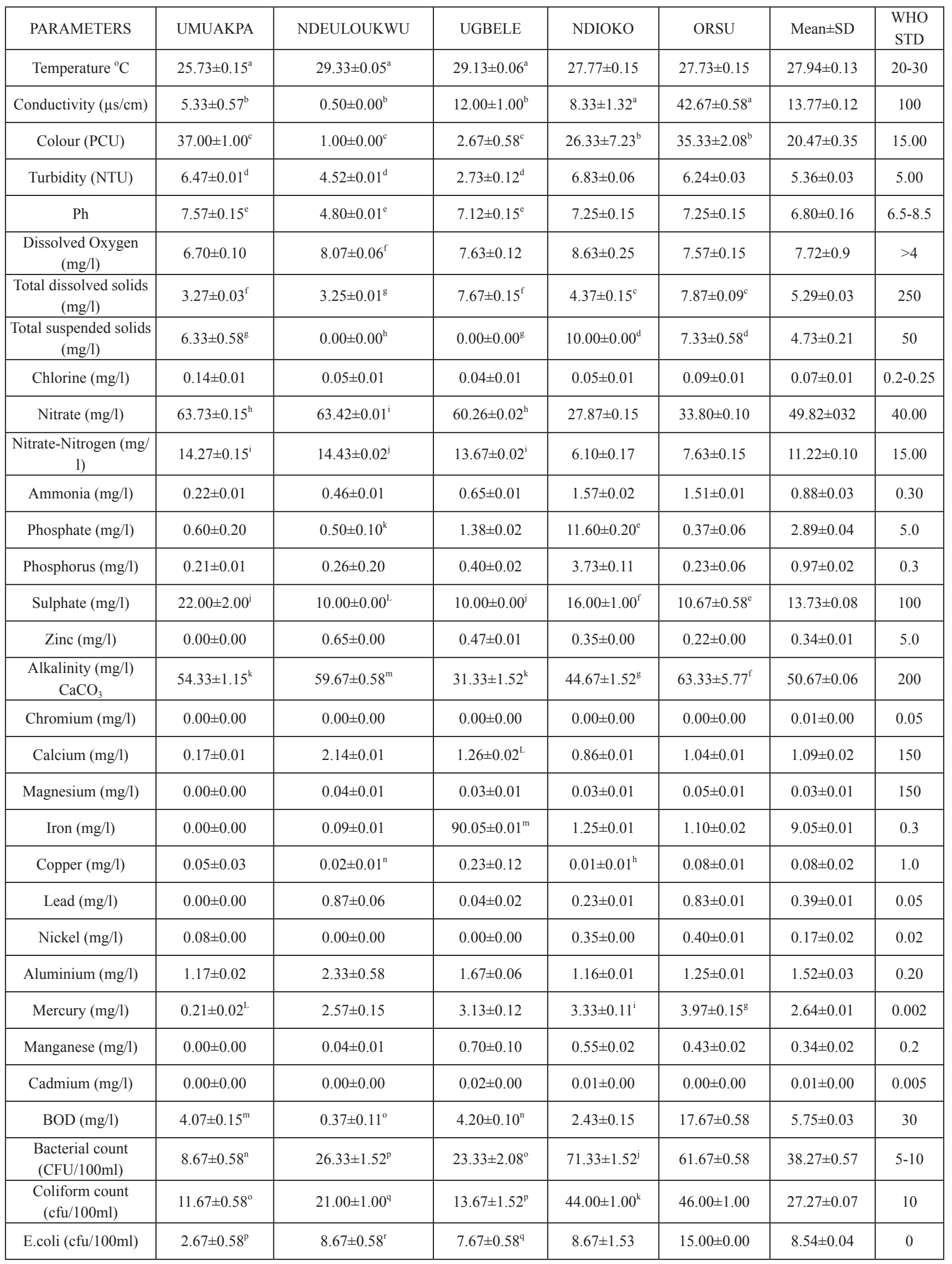


Journal of Environmental \& Earth Sciences | Volume 03 | Issue 02 | October 2021

Table 3. Comparison of groundwater physicochemical and microbial parameters in Izombe with WHO standard

\begin{tabular}{|c|c|c|c|c|}
\hline PARAMETERS & IZOMBE & WHO & T-TEST & P-VALUE \\
\hline Temperature ${ }^{\circ} \mathrm{C}$ & $28.09 \pm 0.15$ & $20-30$ & 13.60 & $<0.001$ \\
\hline Conductivity $(\mu \mathrm{s} / \mathrm{cm})$ & $25.82 \pm 0.14$ & 100 & 15.06 & $<0.001$ \\
\hline Colour (PCU) & $23.89 \pm 0.25$ & 15.00 & 0.937 & 0.404 \\
\hline Turbidity (NTU) & $7.59 \pm 0.02$ & 5.00 & 0.583 & 0.591 \\
\hline $\mathrm{Ph}$ & $6.42 \pm 0.28$ & $6.5-8.5$ & 0.216 & 0.840 \\
\hline Dissolved Oxygen (mg/l) & $6.93 \pm 0.09$ & $>4$ & 5.813 & 0.004 \\
\hline Total dissolved solids (mg/l) & $16.76 \pm 0.04$ & 250 & 74.828 & $<0.001$ \\
\hline Total suspended solids (mg/l) & $5.14 \pm 0.15$ & 50 & 19.348 & $<0.001$ \\
\hline Chlorine (mg/l) & $0.16 \pm 0.02$ & $0.2-0.25$ & 2.054 & 0.109 \\
\hline Nitrate $(\mathrm{mg} / \mathrm{l})$ & $59.56 \pm 0.50$ & 40.00 & 1.024 & 0.364 \\
\hline Nitrate-Nitrogen (mg/l) & $13.89 \pm 0.3$ & 15.00 & 0.267 & 0.803 \\
\hline Ammonia (mg/l) & $0.29 \pm 0.07$ & 0.30 & 0.076 & 0.943 \\
\hline Phosphate (mg/l) & $0.88 \pm 0.03$ & 5.0 & 24.65 & $<0.001$ \\
\hline Phosphorus (mg/l) & $0.28 \pm 0.02$ & 0.3 & 0.324 & 0.762 \\
\hline Sulphate (mg/l) & $5.13 \pm 0.15$ & 100 & 268.0 & $<0.001$ \\
\hline Zinc $(\mathrm{mg} / \mathrm{l})$ & $0.02 \pm 0.01$ & 5.0 & 734.8 & $<0.001$ \\
\hline Alkalinity $(\mathrm{mg} / \mathrm{l}) \mathrm{CaCO}_{3}$ & $27.92 \pm 0.03$ & 200 & 14.97 & $<0.001$ \\
\hline Chromium (mg/l) & $0.01 \pm 0.00$ & 0.05 & 11.23 & $<0.001$ \\
\hline Calcium (mg/l) & $0.17 \pm 0.02$ & 150 & 753.4 & $<0.001$ \\
\hline Magnesium (mg/l) & $0.002 \pm 0.01$ & 150 & 7499 & $<0.001$ \\
\hline Iron $(\mathrm{mg} / \mathrm{l})$ & $0.33 \pm 0.01$ & 0.3 & 0.178 & 0.867 \\
\hline Copper (mg/l) & $2.37 \pm 0.03$ & 1.0 & 1.022 & 0.365 \\
\hline Lead $(\mathrm{mg} / \mathrm{l})$ & $0.50 \pm 0.01$ & 0.05 & 3.355 & 0.028 \\
\hline Nickel (mg/l) & $0.00 \pm 0.00$ & 0.02 & 0.000 & - \\
\hline Aluminium (mg/l) & $1.65 \pm 0.02$ & 0.20 & 14.73 & $<0.001$ \\
\hline Mercury (mg/l) & $2.35 \pm 0.04$ & 0.002 & 3.144 & 0.035 \\
\hline Manganese (mg/l) & $0.22 \pm 0.01$ & 0.2 & 0.333 & 0.756 \\
\hline Cadmium (mg/l) & $0.00 \pm 0.00$ & 0.005 & 0.000 & - \\
\hline BOD (mg/l) & $4.92 \pm 0.01$ & 30 & 12.34 & $<0.001$ \\
\hline Bacterial count $(\mathrm{cfu} / 100 \mathrm{ml})$ & $27.53 \pm 0.58$ & $5-10$ & 0.218 & 0.838 \\
\hline Coliform count (cfu/100ml) & $14.99 \pm 0.24$ & 10 & 0.691 & 0.528 \\
\hline E.coli $(\mathrm{cfu} / 100 \mathrm{ml})$ & $6.93 \pm 0.29$ & 0 & 1.765 & 0.152 \\
\hline
\end{tabular}

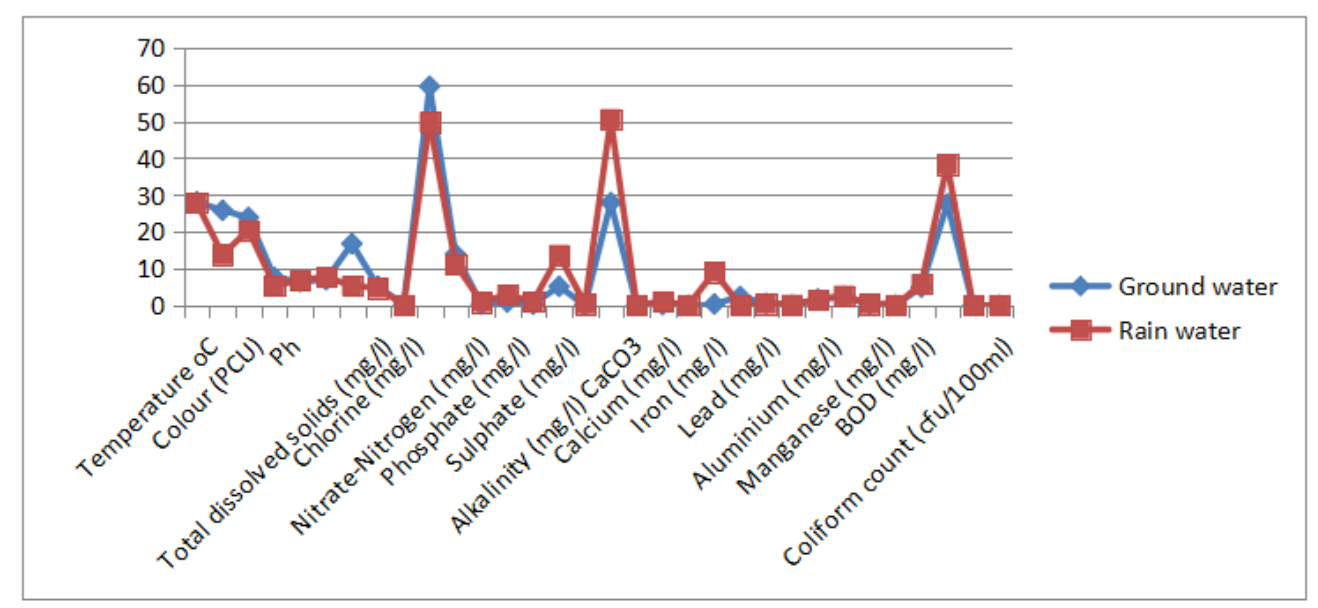

Figure 1. Comparison of groundwater and rainwater physicochemical and microbial parameters in Izombe 
Table 4. Comparison of rainwater physicochemical and microbial parameters in Izombe with WHO standard

\begin{tabular}{|c|c|c|c|c|}
\hline PARAMETERS & IZOMBE & WHO & T-TEST & \\
\hline Temperature ${ }^{\circ} \mathrm{C}$ & $27.94 \pm 0.13$ & $20-30$ & 3.2 & 0.033 \\
\hline Conductivity $(\mu \mathrm{s} / \mathrm{cm})$ & $13.77 \pm 0.12$ & 100 & 11.54 & $<0.001$ \\
\hline Colour (PCU) & $20.47 \pm 0.35$ & 15.00 & 0.699 & 0.523 \\
\hline Turbidity (NTU) & $5.36 \pm 0.03$ & 5.00 & 0.466 & 0.665 \\
\hline $\mathrm{Ph}$ & $6.80 \pm 0.16$ & $6.5-8.5$ & 0.590 & 0.587 \\
\hline Dissolved Oxygen (mg/l) & $7.72 \pm 0.9$ & $>4$ & 11.701 & $<0.001$ \\
\hline Total dissolved solids (mg/l) & $5.29 \pm 0.03$ & 250 & 236.5 & $<0.001$ \\
\hline Total suspended solids (mg/l) & $4.73 \pm 0.21$ & 50 & 22.38 & $<0.001$ \\
\hline Chlorine (mg/l) & $0.07 \pm 0.01$ & $0.2-0.25$ & 9.46 & 0.001 \\
\hline Nitrate (mg/l) & $49.82 \pm 032$ & 40.00 & 1.254 & 0.278 \\
\hline Nitrate-Nitrogen (mg/l) & $11.22 \pm 0.10$ & 15.00 & 2.101 & 0.103 \\
\hline Ammonia (mg/l) & $0.88 \pm 0.03$ & 0.30 & 2.099 & 0.104 \\
\hline Phosphate (mg/l) & $2.89 \pm 0.04$ & 5.0 & 0.966 & 0.389 \\
\hline Phosphorus (mg/l) & $0.97 \pm 0.02$ & 0.3 & 0.963 & 0.390 \\
\hline Sulphate (mg/l) & $13.73 \pm 0.08$ & 100 & 36.66 & $<0.001$ \\
\hline Zinc (mg/l) & $0.34 \pm 0.01$ & 5.0 & 42.29 & $<0.001$ \\
\hline Alkalinity $(\mathrm{mg} / \mathrm{l}) \mathrm{CaCO}_{3}$ & $50.67 \pm 0.06$ & 200 & 25.90 & $<0.001$ \\
\hline Chromium (mg/l) & $0.01 \pm 0.00$ & 0.05 & 0.000 & - \\
\hline Calcium (mg/l) & $1.09 \pm 0.02$ & 150 & 467.03 & $<0.001$ \\
\hline Magnesium (mg/l) & $0.03 \pm 0.01$ & 150 & 179.6 & $<0.001$ \\
\hline $\operatorname{Iron}(\mathrm{mg} / \mathrm{l})$ & $9.05 \pm 0.01$ & 0.3 & 1.170 & 0.307 \\
\hline Copper (mg/l) & $0.08 \pm 0.02$ & 1.0 & 23.09 & $<0.001$ \\
\hline Lead (mg/l) & $0.39 \pm 0.01$ & 0.05 & 1.808 & 0.145 \\
\hline Nickel (mg/l) & $0.17 \pm 0.02$ & 0.02 & 1.680 & 0.168 \\
\hline Aluminium (mg/l) & $1.52 \pm 0.03$ & 0.20 & 5.875 & 0.004 \\
\hline Mercury (mg/l) & $2.64 \pm 0.01$ & 0.002 & 4.075 & 0.015 \\
\hline Manganese (mg/l) & $0.34 \pm 0.02$ & 0.2 & 1.035 & 0.359 \\
\hline Cadmium (mg/l) & $0.01 \pm 0.00$ & 0.005 & 0.250 & 0.815 \\
\hline BOD (mg/l) & $5.75 \pm 0.03$ & 30 & 7.925 & 0.001 \\
\hline Bacterial count $(\mathrm{cfu} / 100 \mathrm{ml})$ & $38.27 \pm 0.57$ & $5-10$ & 2.354 & 0.078 \\
\hline Coliform count $(\mathrm{cfu} / 100 \mathrm{ml})$ & $27.27 \pm 0.07$ & 10 & 2.330 & 0.080 \\
\hline E.coli $(\mathrm{cfu} / 100 \mathrm{ml})$ & $8.54 \pm 0.04$ & 0 & 4.351 & 0.012 \\
\hline
\end{tabular}

\section{Discussion}

\subsection{Physico-chemical Quality of Izombe Rainwater}

The presence of color and turbidity in rainwater in Izombe is brought about by industrial pollution occasioned by gas flair and petrochemical products and the high level of nitrates and ammonia lead to acid rain in Izombe. A high level of heavy metals such as iron, lead, nickel, aluminum, mercury, and cadmium in the area is due to the oil exploratory activities by the use of heavyduty machinery. Communities located closer to the oil wells such as Ugbele and Ndioko show a higher level of rainwater contamination of iron with values of $90+0.01$ $\mathrm{mg} / \mathrm{l}$ for Ugbele and $1.25+0.01 \mathrm{mg} / \mathrm{l}$ for Ndioko as against the WHO standard value of $0.3 \mathrm{mg} / \mathrm{l}$. Ugbele community showed a markedly high level of contamination of rainwater with mercury with the value of $3.13+0.12 \mathrm{mg} / 1$ when compared with other communities located far away from the oil wells such as Umuakpa with the value of $0.21+0.02 \mathrm{mg} / \mathrm{l}$. (Table 1).

The results of the physicochemical parameters of rainwater in Izombe show that color and turbidity gave higher values than the WHO's acceptable standard value. Turbidity was related to the presence of particles of clay, organic components, and other microscopic substances that make the water unhealthy for human consumption. The findings ${ }^{[11]}$, it is an indication of deposits of pollutant loads or dissolved particles. In Izombe as an oil-producing 
community, rainwater turbidity is commonly due to the dissolution of particulate matter, generated from oil production emissions. The total dissolved solids (TDS) and conductivity values in rainwater are generally lower than that of groundwater.

The high value of Nitrate in the rainwater constitutes acidity in water found in the area. The source is traced to the dissolution in rainwater of acidic gases including $\mathrm{CO}_{2}$, $\mathrm{NO}_{2}$, and $\mathrm{SO}_{2}$ that originate from gas flares, industrial generators, and vehicular exhaust fumes ${ }^{[12]}$. Ammonia was found to be of a very high level beyond WHO's acceptable standard value in rainwater. This is an indication of the high rate of atmospheric pollution by gas fumes from industrial sources.

\subsection{Microbial Quality of Izombe Rainwater}

The sanitary quality of rainwater in the study area was assessed by its bacteriological composition. In Table 2, which shows that the bacteria count, coliform, and E-coli are exceptionally higher than the WHO values? The presence of these microbes may partly be explained by the mode of sample collection and partly by the fact that the aqueous particulates in the atmosphere can harbor spores of microorganisms that are washed down during rainfall. Rainwater samples were collected directly into containers as they fell through the atmosphere. Usually, serious microbial contamination only begins after contact with collection surfaces, such as roofing materials ${ }^{[13]}$.

\subsection{Physico-chemical Quality of Izombe Groun- dwater}

The presence of color and turbidity in groundwater in Izombe is brought about by industrial pollution occasioned by gas flair and petrochemical products and the high level of nitrates and ammonia lead to acid rain in Izombe. A high level of heavy metals such as iron, lead, nickel, aluminum, mercury, and cadmium in the area is due to the oil exploratory activities by the use of heavyduty machinery.

Ugbele community located closer to oil wells showed a markedly higher level of contamination of groundwater with mercury with values of $5.02+0.06 \mathrm{mg} / 1$ when compared with other communities located far away from the oil wells such as Umuakpa with a value of $2.30+0.10 \mathrm{mg} / \mathrm{l}$.

The results of the physicochemical parameters of groundwater in Izombe agree with the opinions of ${ }^{[14]}$, who stated that turbidity can be related to the presence of particles of clay, organic components, and other microscopic substances that make the water unhealthy for human consumption. The findings of ${ }^{[1]}$, it is an indication of deposits of pollutant loads or dissolved particles. In Izombe as an oil-producing community, groundwater turbidity is commonly due to the dissolution of particulate matter, generated from oil production emissions which when dissolved in rainfall return back to the ground and thus polluting the aquifer. The total dissolved solids (TDS) and conductivity values in rainwater are generally lower than that of groundwater. Ammonia was found to be of a very high level beyond WHO's acceptable standard value in groundwater. This is an indication of the high rate of atmospheric pollution by gas fumes from industrial sources which later find their way into the soil.

\subsection{Microbial Quality of Izombe Groundwater}

The microbial contamination of groundwater in the area is attributable to the unsanitary habits of the inhabitants.

The sanitary quality of groundwater in the study area was assessed by its bacteriological composition. Tables 1and 2 indicate that the bacteria count, coliform, and E-coli are exceptionally high in groundwater when compared with the WHO standard values. Results obtained from groundwater samples indicate high total coliform counts that exceed the ${ }^{[5]}$ standard for water portability. The high coliform counts suggest that groundwater in the study area may be potentially harmful. The ingress of coliform bacteria may have been facilitated by the shallow nature $(0-4.3 \mathrm{~m})$ of the aquifer, which enables easy access by percolating contaminated water.

\subsection{Environmental and Health Implications}

The result of this study and several others indicate that the accelerated economic and population growth brought about by the oil exploration and production activities in the study area gave rise to adverse environmental and health impacts.

The massively enhanced values of $\mathrm{SO}_{4}{ }^{2-}$ and $\mathrm{NO}^{3-}$ in rainwater relative to groundwater indicates quality degradation in rainwater and suggests substantial pollution of the atmosphere from which $\mathrm{SO}_{2}$ and $\mathrm{NO}_{2}$ gases were scavenged by the falling rainwater. $\mathrm{SO}_{2}$ and $\mathrm{NO}_{2}$ gases are actively poisonous and irritating both to the skin and lungs. Besides, $\mathrm{SO}_{2}$ and $\mathrm{NO}_{2}$ are dissolved by rainwater to produce weak $\mathrm{H}_{2} \mathrm{SO}_{4}$ and $\mathrm{HNO}_{3}$, which fall on the earth as acid rain, with corrosive effects. Recent studies indicate that $\mathrm{SO}_{4}{ }^{2-}$ and $\mathrm{NO}^{3-}$ contributed more than $75 \%$ of free acidity in rainfall in the Izombe area ${ }^{[12]}$.

Secondly, the result of acid rain in the study area is evident. Visual observation showed that stationary structures, roofing sheets, and other metallic objects are usually very rapidly weathered thereby reducing their 
shelf life. Also, the gaseous emissions have been linked to the increased greenhouse effect and the establishment of local heat islands in the area. The atmospheric content of greenhouse gases of $\mathrm{CO}_{2}, \mathrm{CO}, \mathrm{NO}, \mathrm{NO}_{2}, \mathrm{SO}_{2}$, and $\mathrm{C}_{12}$ in built-up and petroleum industrial areas is significantly higher than in the countryside ${ }^{[15]}$. These areas are consequently warmer by about $9^{0} \mathrm{C}$ during the day and $2^{\circ} \mathrm{C}$ at night and are less humid by about $15 \%$ relative to the countryside.

The measured Lead $(\mathrm{Pb})$ concentrations of rain and groundwater samples are higher than ${ }^{[5]}$

recommended maximum value. The toxic effects of excessive Lead $(\mathrm{Pb})$ levels in humans include significant damage on the brain of both adults and infants ${ }^{[16]}$. It is also known to induce heart-related diseases ${ }^{[17]}$.

Furthermore, the rapid population growth that outpaced public utility development and the unsanitary habits of the residents is reflected in the high coliform load in groundwater within the study area. Although the water samples were not tested for specific pathogens, the high microbial population present suggests that it may be harmful to health.

\subsection{Conclusions}

From the study, there is an agreement among scholars that water quality is determined by the degree or value of pollutants present. To this end, the researcher in his findings indicates that there are pollutants in varying levels in Izombe rain and groundwater. The values of these measured parameters in rain and groundwater were however compared with their values with WHO standards. The differences in values of the pollutants found in rainwater from those in groundwater may be explained as the result of their different sources as well as the movement of the pollutants.

The laboratory results show that the groundwater had higher values of Copper, Nickel, Lead and Mercury iron, Aluminum, BOD, Bacterial count, Coliform, and E-Coli than rainwater. The total dissolved solids, gases, and chemicals also went beyond acceptable WHO standards, thereby constituting groundwater pollutants in Izombe. Rainwater recorded a greater value of Turbidity, Sulphate, Nitrate, Phosphorous, Ammonia, and Manganese, than groundwater and far beyond the acceptable limit by WHO standard. These parameters are therefore the registered rainwater pollutants in Izombe.

Based on the ${ }^{[5]}$ specifications, the groundwater cannot, therefore, be acceptable as potable owing to its high coliform counts, bacterial and other impurities from dissolved solids, gases, and chemicals, while enhanced Turbidity, Sulphate, Nitrate, and Phosphorous concentration, on the other hand, makes the rainwater acidic and so objectionable.

\subsection{Recommendations}

The researcher wishes to recommend as follows:

Earlier, the government of Nigeria had set the year 2008 to end all gas flaring activities by oil companies operating in the Niger Delta area. But this failed to fruition. All relevant authorities should put machinery in motion to ensure that these health and environmental hazardous activities are stopped.

Local communities, especially oil company hosts, should be very conscious of their environment, avoid and prevent unhealthy practices mostly such that generate water pollution.

There should be enforced and supervised better sanitation practices in the rural and urban communities.

The degenerating trend of water resources quality in our community should be reversed.

Bush burning and chemical farming should be put under strict control.

Oil and gas producing and processing companies should be made to pay commensurable compensation to host communities like Izombe for being the principal architect of their health and environmental disorder.

\section{Conflicts of Interest}

The author hereby declares that he has no conflict of interest.

\section{References}

[1] Byrd D. and Eleanor I. (2002). "Moon's Day and Night." Earth and Sky. April 27, 2002.

[2] Chaplin M. (2004). "Water Structure and Behavior." London South Bank University, London, England.

[3] Glen E.M. (2014). The Chemistry of Biology: Water Alpha Books, USA http://www.infoplease.com/cig/ biology/water.html\#ixzz31m8IastQ.

[4] Prüss-Üstün A. and Corvalán C.F. (2006). Preventing disease through healthy environments towards an estimate of the environmental burden of disease, Geneva: World Health Organization.

[5] World Health Organization (2006). Guidelines for drinking-water quality: incorporating first addendum: Vol. 1- Recommendations. 3rd edition. Geneva.

[6] Egborge A.B.M. (1991). Industrialization and heavy metal pollution in Warri River. 32nd inaugural lecture, University of Benin, Nigeria.

[7] Olobaniyi S.B. and Efe S.I. (2007). Comparative assessment of rainwater and groundwater quality in 
an oil-producing area of Nigeria: environmental and health implications; Department of Geology, Delta State University, Nigeria.

[8] Seip H.M. and Tollan A. (1985). Acid deposition; in Rodda H, and Wiley C J., (Eds.), Facets of Hydrology Vol. 2.

[9] Oparaocha, E.T., Iroegbu, O.C. and Obi, R.K. (2011). Assessment of quality of drinking water sources in the Federal University of Technology, Owerri, Imo state, Nigeria. Journal of Applied Biosciences. 32: $1964-1976$.

[10] APHA. (2005). Standard Methods for the Examination of Water and Waste Water, 21st ed. American Public Health Association Pp 1-252.

[11] Efe S.I. (2005). Urban effects on precipitation amount, distribution, and rainwater quality in Warri metropolis. Ph.D. Thesis, Department of Geography and Regional Planning, Delta State University, Abraka, Nigeria.

[12] Ogunkoya O.O. and Efe E.J. (2003). Rainfall quality and sources of rainwater acidity in the Warri area of the Niger Delta, Nigeria. Journal of Mining and Ge- ology, 39(2), 125-130.

[13] Gould J.E. and McPherson H.J. (1987). Bacteriological quality of river water in roof and ground catchment system in Botswana. Water International, 12, 135-138.

[14] Sangodoyin, A.Y. (1991).Ground Water and Surface Water Pollution by Open Refuse dump in Ibadan, Nigeria, Discovery and Innovations. Vol. 3(1): 24 - 31.

[15] Efe S.I. (2002). Urban warming in Nigeria cities: the case of Warri metropolis. African Journal of Environmental Studies, 3, 160-168.

[16] Foster, S., Hirata, R., Gomes, D., D’Elia, M. and Paris, M. (2002a). Groundwater quality Protection: a guide for water utilities, municipal authorities and environment agencies. World Bank Publication, Washington DC, USA. Pp 1-116.

[17] Kopp S.J., Barron J.T. and Tow J.P. (1988). Cardiovascular actions of lead and relationship to hypertension; a review. Environmental Health Perspectives, 78, 91-99. 